\title{
The prion protein regulates beta-amyloid-mediated self-renewal of neural stem cells in vitro
}

\author{
Steven J Collins ${ }^{1,2,3^{*}}$, Carolin Tumpach ${ }^{3}$, Qiao-Xin Li ${ }^{3}$, Victoria Lewis ${ }^{1}$, Timothy M Ryan ${ }^{3}$, Blaine Roberts ${ }^{3}$, \\ Simon C Drew ${ }^{4}$, Victoria A Lawson ${ }^{1}$ and Cathryn L Haigh ${ }^{1 *}$
}

\begin{abstract}
The beta-amyloid $(A \beta)$ peptide and the A $A$-oligomer receptor, prion protein (PrP), both influence neurogenesis. Using in vitro murine neural stem cells (NSCs), we investigated whether A 3 and PrP interact to modify neurogenesis. A $\beta$ imparted PrP-dependent changes on NSC self-renewal, with PrP-ablated and wild-type NSCs displaying increased and decreased cell growth, respectively. In contrast, differentiation of A $\beta$-treated NSCs into mature cells was unaffected by PrP expression. Such marked PrP-dependent differences in NSC growth responses to A $\beta$ provides further evidence of biologically significant interactions between these two factors and an important new insight into regulation of NSC self-renewal in vivo.
\end{abstract}

\section{Findings} Introduction

Alzheimer's disease (AD) is the most common form of dementia. The core components of the senile plaques that characterise AD pathologically are beta-amyloid $(\mathrm{A} \beta)$ peptides cleaved from the amyloid precursor protein (APP). Various $A \beta$ species exist as a result of differing $\mathrm{N}$ - and $\mathrm{C}$-terminal processing sites and these species can aggregate, forming oligomers that are implicated in $A \beta$ toxicity [1]. Most $A \beta$ species are found in healthy brain tissue but the relative amounts shift during $\mathrm{AD}[2,3]$. In health, $\mathrm{A} \beta 1-40$ predominates and during $A D A \beta 1-42, A \beta 4-42$ and pyroglutamated $A \beta 3-$ $42(3(\mathrm{pE})-42)$ are increased [3]. Many other species also exist with their relative amounts changing during disease.

Neurogenesis, whilst declining significantly in the adult organism, continues throughout life. Adult neural stem cells (NSCs) are confined to specific protected sites within the brain, including the sub-granular zone (SGZ) of the dentate gyrus and sub-ventricular zone of the lateral ventricle [4]. Adult NSCs can self-renew and are multipotent; they can differentiate into cells of any central nervous

\footnotetext{
*Correspondence: stevenjc@unimelb.edu.au; chaigh@unimelb.edu.au 'Department of Pathology, The University of Melbourne, Melbourne Brain Centre, Melbourne, VIC 3010, Australia

${ }^{3}$ Florey Department of Neuroscience and Mental Health, The University of Melbourne, Melbourne, VIC 3010, Australia

Full list of author information is available at the end of the article
}

system lineage. In the brains of $\mathrm{AD}$ patients, markers of neurogenesis are increased [5,6] indicating potential neurogenic dysregulation or stimulated compensation for neuronal loss. AD pathology typically begins in the transentorhinal and entorhinal cortex [7]. This region lies adjacent to the SGZ and, therefore, NSCs in their normally protected niche environment may be exposed to hostile conditions that stimulate them to change their behaviour [4]. There is significant evidence that $A \beta$ peptides are able to modulate neurogenesis [8-10]. Various discrepancies exist in the literature as to whether neurogenesis is enhanced or suppressed by $A \beta$ exposure, which is most likely due to the manner in which the $A \beta$ was prepared (that is, if monomeric, oligomeric or fibrillar $A \beta$ species were used) and the model system for NSC study (for example, in vivo, in vitro, mouse strain); however, the consensus is in favour of changed NSC behaviour following exposure to $A \beta$ species.

Neurogenesis is also modulated by another neurodegenerative disease-associated protein, the prion protein (PrP) [11,12]. Increased PrP expression is associated with increased cell cycling at the expense of differentiation [13]. Recent studies found that $\operatorname{PrP}$ is an essential receptor that transduces soluble $A \beta 1-42$ oligomer signals from the plasma-membrane through the NMDA receptor via the signalling molecule fyn to tau, with this signalling thought to cause cellular toxicity [14-16]. Based on the knowledge that both $\mathrm{A} \beta$ and PrP can individually 
modulate neurogenesis and that $\operatorname{PrP}$ is a soluble $\mathrm{A} \beta 1-42$ binding partner necessary for the transduction of toxic signals, we hypothesized that PrP might also transduce the $A \beta$ peptide signals that alter neurogenesis. The present study therefore investigated the ability of various $\mathrm{A} \beta$ peptides to modulate in vitro self-renewal and differentiation of adult NSCs harvested from PrP gene-ablated (knock-out $(\mathrm{KO})$ ) or from wild-type (WT; normal PrP expression) mice.

\section{Methods}

A $\beta$-amyloid peptides (China Peptides, China) were prepared as described previously [17]. NSC harvest and routine culture was as described previously $[18,19]$. For

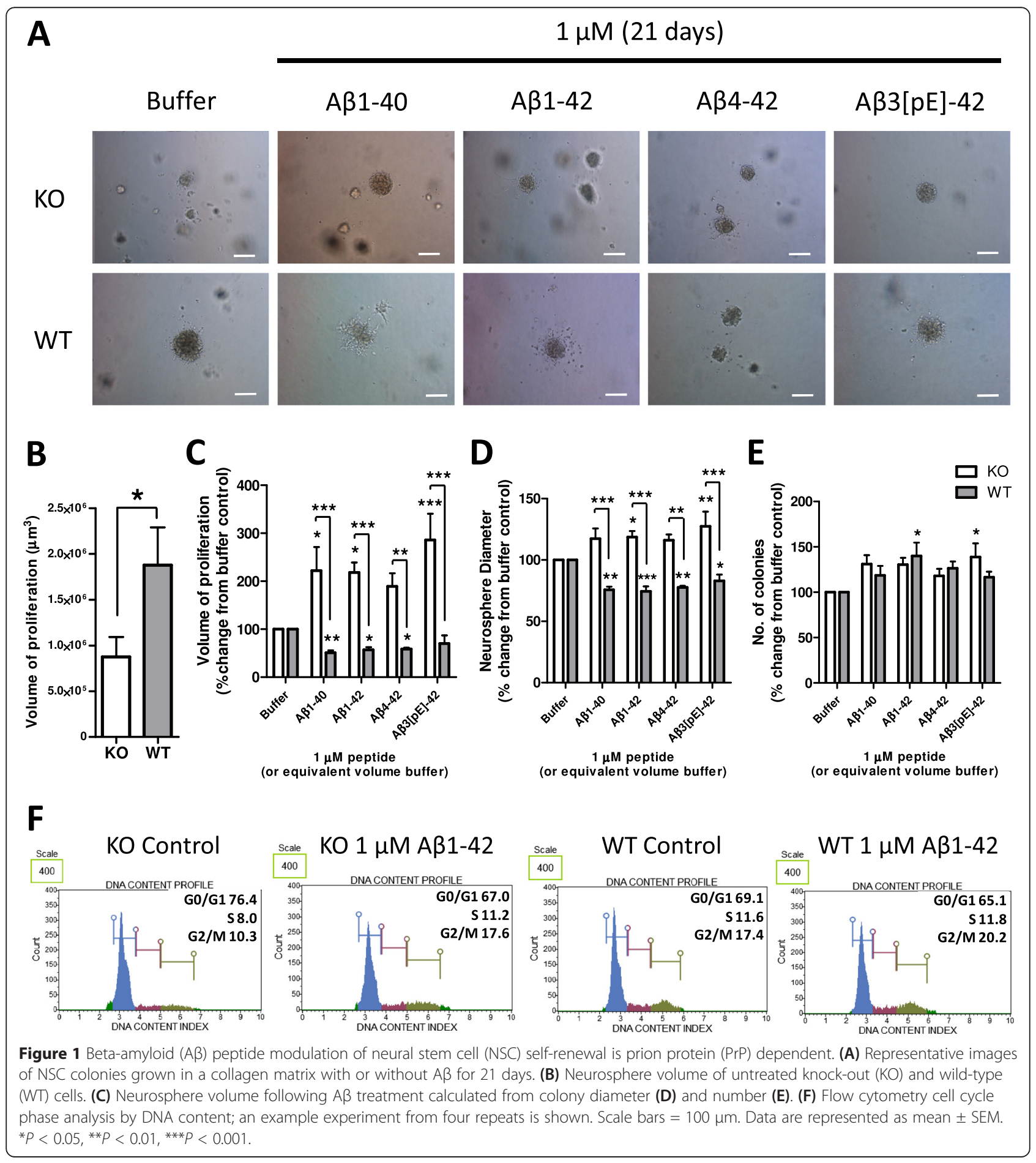




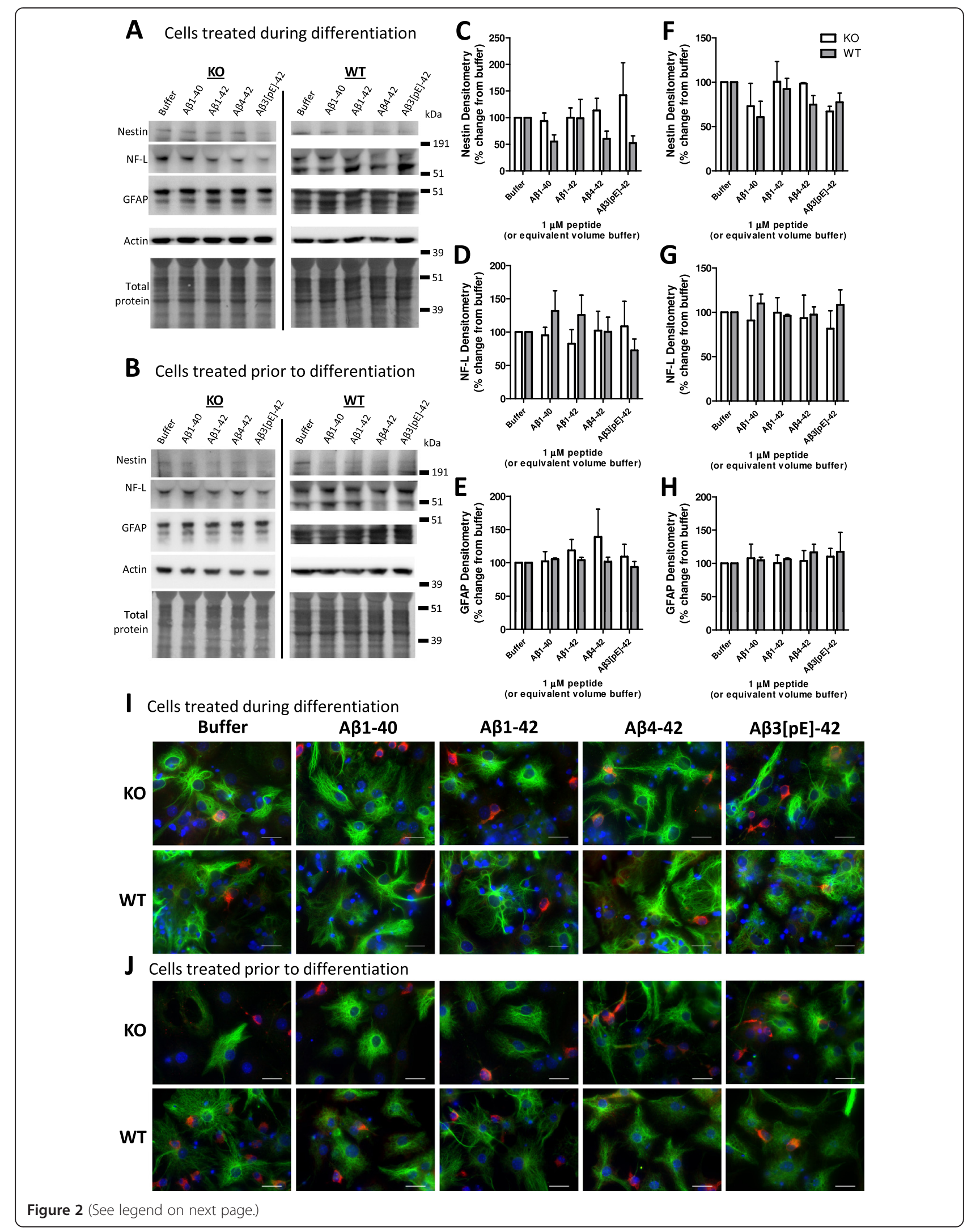


(See figure on previous page.)

Figure 2 Prion protein (PrP) expression has minimal influence on how beta-amyloid (A $\beta$ ) affects neural stem cell (NSC) differentiation. Example plates of western blots for lineage protein markers from knock-out (KO) and wild-type (WT) NSCs treated for either 7 days during differentiation (A) or 24 hours prior to differentiation for 7 days (B) with $1 \mu \mathrm{M} A \beta$. Quantification of the western blots (A \& B) for the stem cell marker nestin $(\mathbf{C}, \mathbf{F})$, mature neuronal marker, NF-L (D, G), and GFAP astrocytic marker $(\mathbf{E}, \mathbf{H})$. Data are represented as mean \pm SEM. Example immunofluorescent images of NSCS treated with A 3 during (I) and before (J) differentiation with NF-L, GFAP and DAPI nuclear staining shown in red, green and blue respectively. Scale bars $=15 \mu \mathrm{m}$.

the neural colony-forming assay, cells were seeded in a semi-solid gel matrix made with a 2:1 solution of proliferation medium and collagen. After day 21, neurospheres were counted and their diameter measured using NISElements (Nikon Adelaide, Australia) software. Cell cycle analysis was performed using the Muse Cell Cycle Kit (Millipore, Bayswater, Victoria AUS). For plate and blotting assays cells were cultured as an adherent monolayer on a 1:1 poly-D-lysine-laminin matrix. Cellular ATP content was measured using Life Sciences' ATP assay (Invitrogen, Mulgrave, Victoria AUS). Immunodetection methods have been described previously [18-20]. Expanded methodology is provided in Additional file 1.

\section{Results and discussion}

Potential $\mathrm{A} \beta-\operatorname{PrP}$ signalled changes in neurogenesis were assessed using four $A \beta$ species; $A \beta 1-40, A \beta 1-42$, $A \beta 4-42$ and $A \beta 3(\mathrm{pE})-42$, representing those that are found 'normally' in health and those that have been linked with cellular toxicity in $\mathrm{AD}[21,22]$. Previous studies have shown that fibrillar $A \beta$ has no effect on neurogenesis [23] and soluble oligomeric $A \beta 42$ is toxic; therefore, $A \beta$ peptides were prepared using an established protocol for producing soluble monomeric species [17]. One $\mu \mathrm{M} A \beta$ peptide was used based on results of previous studies that demonstrated this concentration induced neurogenic effects [24]. No toxicity was observed at this concentration throughout the duration of the assays (Additional file 2).

NSCs are defined by their properties of self-renewal and differentiation into mature cells of any central nervous system lineage. First we assessed the role of PrP in modifying NSC self-renewal using a neural colonyforming assay, which considers both the number of cells able to form new clonal colonies and the size of the colonies formed as an indication of clonal growth rate. As previously reported, $\operatorname{PrP}$ expression positively influenced NSC self-renewal (two-way analysis of variance (ANOVA), $\mathrm{F}=7.84, P=0.006, \mathrm{n}=4$; Figure $1 \mathrm{~A} \& \mathrm{~B})$ [11-13]. To determine whether $\operatorname{PrP}$ has a role in transducing $A \beta$ mediated changes in NSC growth, WT and KO NSCs were incubated with the $A \beta$ species described above. The KO cells showed a significantly greater proliferation volume when compared with the carrier buffer alone and equivalently treated WT NSCs for all A $\beta$ species (two-way ANOVA, $\mathrm{F}=53.75, P<0.001, \mathrm{n}=4$, see Additional file 3 for complete statistical analyses; Figure 1A \& C). The difference was primarily due to increased diameter of the $\mathrm{A} \beta$-treated $\mathrm{KO}$ colonies (Figure 1D) in contrast to a decreased diameter of the WT NSCs exposed to A $\beta$ (twoway ANOVA, $\mathrm{F}=63.43, P<0.001, \mathrm{n}=4$ ), as the number of colonies formed was not significantly different between the WT and KO NSCs (Figure 1E). Proliferation of Tga20 (PrP overexpressing) NSCs treated with $A \beta$ showed similar changes to those observed for WT cells, with no apparent PrP dose-effect at the concentration of $\mathrm{A} \beta$ used (Additional file 4). The presence of $\operatorname{PrP}$ did not confer a greater susceptibility to any one species of $A \beta$, indicating that neither the $\mathrm{N}$ - nor C-terminal truncation of $A \beta$ is important for induction of growth changes or interaction with $\operatorname{PrP}$ but that the core of the peptide appears sufficient.

To further assess differences in NSC growth, A $\beta 1-42$ was used to assess the number of cells in each phase of the cell cycle 24 hours post- $\mathrm{A} \beta$ addition to liquid culture. More KO cells rested in G0/G1 basally than WT (two-way ANOVA, $\mathrm{F}=22.99, P=0.003, \mathrm{n}=4$ ) but after treatment with $\mathrm{A} \beta$ the number of $\mathrm{KO}$ cells actively cycling (S, G2/M phases) was significantly increased (two-way ANOVA for $\mathrm{S}$ phase, $\mathrm{F}=39.18, P=0.003, \mathrm{n}=4$; for $\mathrm{G} 2 / \mathrm{M}$ phases, $\mathrm{F}=24.91, P=0.003, \mathrm{n}=4$; Figure $1 \mathrm{~F}$ ). There was no significant change for the WT cells, suggesting that the changes that slow the growth and reduce the diameter of neurospheres may occur after a longer period of exposure to $\mathrm{A} \beta$.

NSCs can be induced to differentiate into neurones, astrocytes and oligodendrocytes. The lineage to which an individual cell commits is influenced by its extracellular environment both before and during stimulation to differentiate. Therefore, NSCs can be manipulated to differentiate into a specific mature cell by their environment. To assess the influence of $\mathrm{A} \beta$ - PrP signalling on NSC differentiation, KO and WT NSCs were either exposed to the $A \beta$ species for 7 days (one treatment only) whilst induced to differentiate or were exposed to the $A \beta$ species for 24 hours before induction of differentiation as an $A \beta$-priming event. When the effect of $A \beta$ on $\mathrm{WT}$ and $\mathrm{KO}$ cellular differentiation was considered, no significant changes were observed in lineage preference regardless of whether $A \beta$ was present during differentiation (two-way ANOVA for nestin, $\mathrm{F}=4.707, P=0.043$ (no individually significant condition), $\mathrm{n}=3$; for NF-L, 
$\mathrm{F}=1.597, P=0.226, \mathrm{n}=3$; for GFAP, $\mathrm{F}=1.514, P=0.223$, $\mathrm{n}=3$; Figure $2 \mathrm{~A}, \mathrm{C}-\mathrm{E}$ ) or if the cells were primed by treatment before differentiation (two-way ANOVA for nestin, $\mathrm{F}=0.616, P=0.442, \mathrm{n}=3$; for NF-L, $\mathrm{F}=0.816, P=0.377$, $\mathrm{n}=3$; for GFAP, $\mathrm{F}=0.266, P=0.611, \mathrm{n}=3$; Figure $2 \mathrm{~B}, \mathrm{~F}-\mathrm{H}$;
Additional file 5). However some morphological changes in WT astrocytes treated with A $\beta 1-42, A \beta 4-42$ and $\mathrm{A} \beta 3(\mathrm{pE})-42$ were observed when cells were treated during, but not when exposed before, differentiation, indicating an influence of the C-terminal two residues (Figure 2I,J).

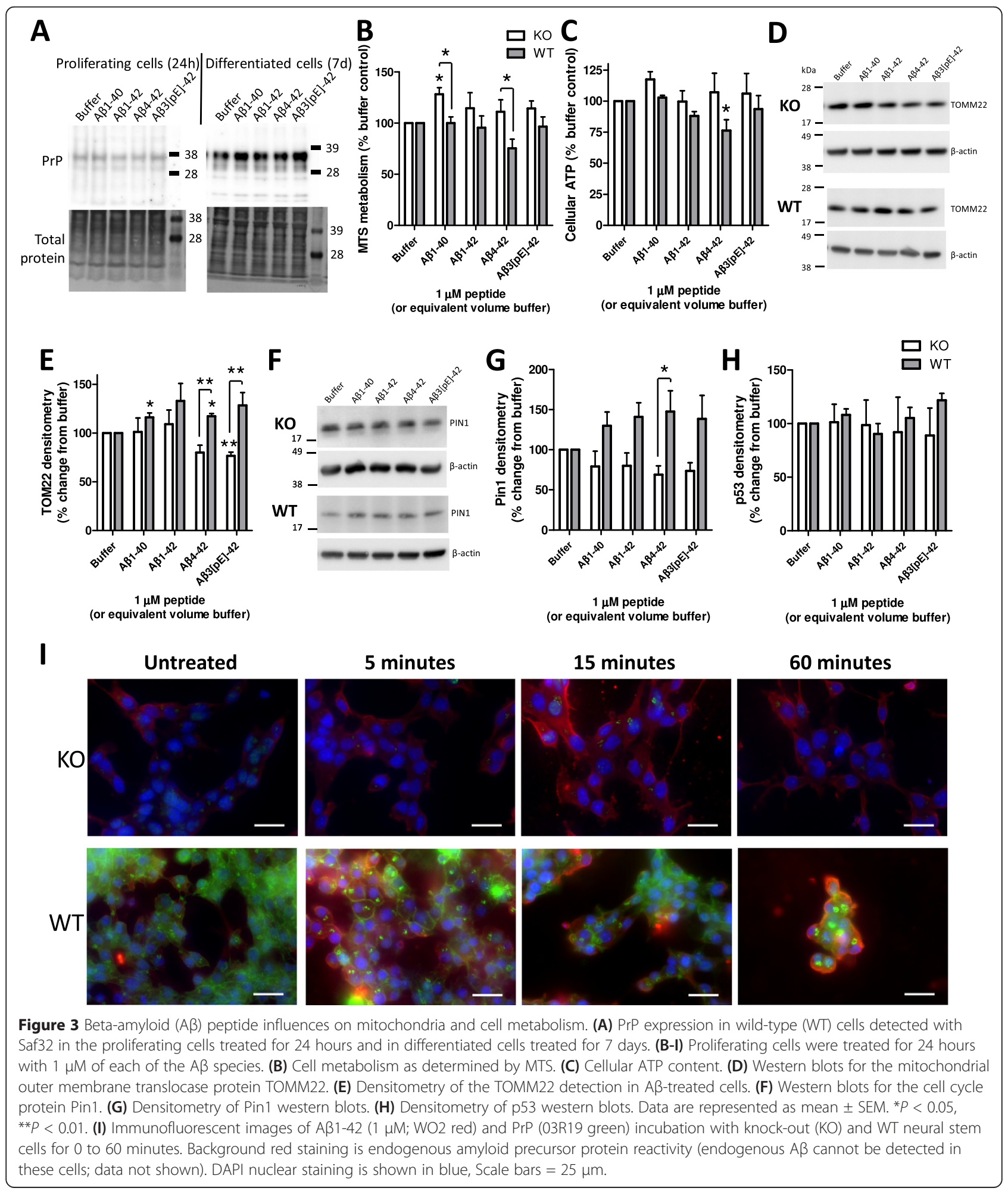


The lack of effect on lineage but morphologic change of WT cells throughout 7 days of $A \beta$ treatment may indicate that developing astrocytic maturity and the changes in cellular protein expression associated may be required for activation of $A \beta x-42$ signalling pathways.

With the most striking $A \beta$ observations relating to opposing changes in self-renewal of the KO and WT cells, it was next considered how these effects might be transduced. Contrary to previous reports [25,26], in the time frames examined no significant influences of $A \beta$ on $\operatorname{PrP}$ expression levels were measurable (Figure 3A; Additional file 6). Whilst chronic exposure may reduce expression over time, in the context of the experiments performed, PrP was present to perform its function.

Changes in the rate of cell cycling are likely to require energy. Therefore, markers of cellular metabolism and mitochondrial function, as well as cell cycle, were compared in WT and KO NSCs following A $\beta$ treatment. Formazan metabolism was significantly increased in NSC KO cells compared with the WT cells when cells were treated with $A \beta 1-40$ and A $44-42$ (two-way ANOVA, $F=16.55$, $P<0.001, \mathrm{n}=3$, see Additional file 5 for basal data and Additional file 7 for full statistical analyses; Figure 3B). Cellular ATP levels were generally unchanged between the KO and WT NSCs, only showing a decrease in WT cells treated with A $\beta 4-42$ (two-way ANOVA, $F=5.95$, $P=0.021, \mathrm{n}=4$; Figure $3 \mathrm{C}$ ). This steady-state ATP measurement does not preclude increased production balanced by increased use. Contrary to decreased growth, TOMM22, a mitochondrial outer membrane translocase, was increased in WT cells when treated with $A \beta 1-40$, $\mathrm{A} \beta 4-42$, and $\mathrm{A} \beta 3(\mathrm{pE})-42$ (two-way ANOVA, $\mathrm{F}=16.45$, $P<0.001, \mathrm{n}=3$; Figure $3 \mathrm{D}, \mathrm{E})$. Potentially, this might indicate that $A \beta$ can exert an effect on mitochondria signalled through PrP that could be detrimental to their function, thus limiting growth. The cell cycle marker Pin1 has also been shown to protect against tau hyperphosphorylation and subsequent changes to the cellular cytoskeleton [27]. Pin1 was globally increased in the $A \beta$-treated WT compared with the KO cells, although only the A $\beta 4-42$ condition was individually significant (two-way ANOVA, $\mathrm{F}=21.98, P<0.001$, $\mathrm{n}=4$; Figure $3 \mathrm{~F}, \mathrm{G}$ ). The overall increase in Pin 1 could reflect a failed effort to increase cell cycling in these cells or might represent a cellular protective response against $A \beta$. p53 is linked with cell cycle and also with cell death. When activated, the half-life of this protein increases resulting in increased protein detection over time. No changes in p53 protein were observed upon treatment with $\mathrm{A} \beta$ in either the $\mathrm{KO}$ or WT NSCs (Figure $3 \mathrm{H}$ ). We additionally considered other previously PrP-linked $A \beta$ signalling pathways (fyn, GSK-3 $\beta$ and calcium) finding no changes in $A \beta$-induced responses that relate to $\operatorname{PrP}$ expression (Additional file 8).
When the localisation of $A \beta$ added to cells was considered relative to $\operatorname{Pr} P$, surface staining of $A \beta$ was observed to be more intense on the WT cells after 1 hour and $\operatorname{PrP}$ surface staining appeared less with greater signal inside the cells (Figure 3I). These findings are consistent with previous studies that have shown $A \beta$ preferentially binds to cells expressing $\operatorname{PrP}$ causing internalisation [28] and also supports the hypothesis that $A \beta$ stimulates different pathways in KO and WT cells.

It remains to be determined how NSCs are affected by PrP-linked $A \beta$ signalling in vivo, where the context of their support cells and scaffold may lead to more diverse outcomes. However, the clear responses of the cells cultured in vitro indicates that sufficient cellular machinery and environmental factors to transduce $\operatorname{PrP}-\mathrm{A} \beta$ signalling cascades are present. The details of these pathways will be revealed by future investigation, but it is of interest that the classical $A \beta$ signalling pathways evaluated here were unaffected. Hypothetically, as PrP-A $\beta$ studies to date were performed in neuronal cultures or mice, different pathways could be engaged in NSCs and postmitotic neurones or, alternatively, differing pathways may be activated when $A \beta$ levels reach toxic concentrations. Furthermore, during sporadic AD, brain $\operatorname{PrP}$ expression reduces [26], inversely correlating with $A \beta$ burden. Reduced PrP expression (akin to KO NSCs) may

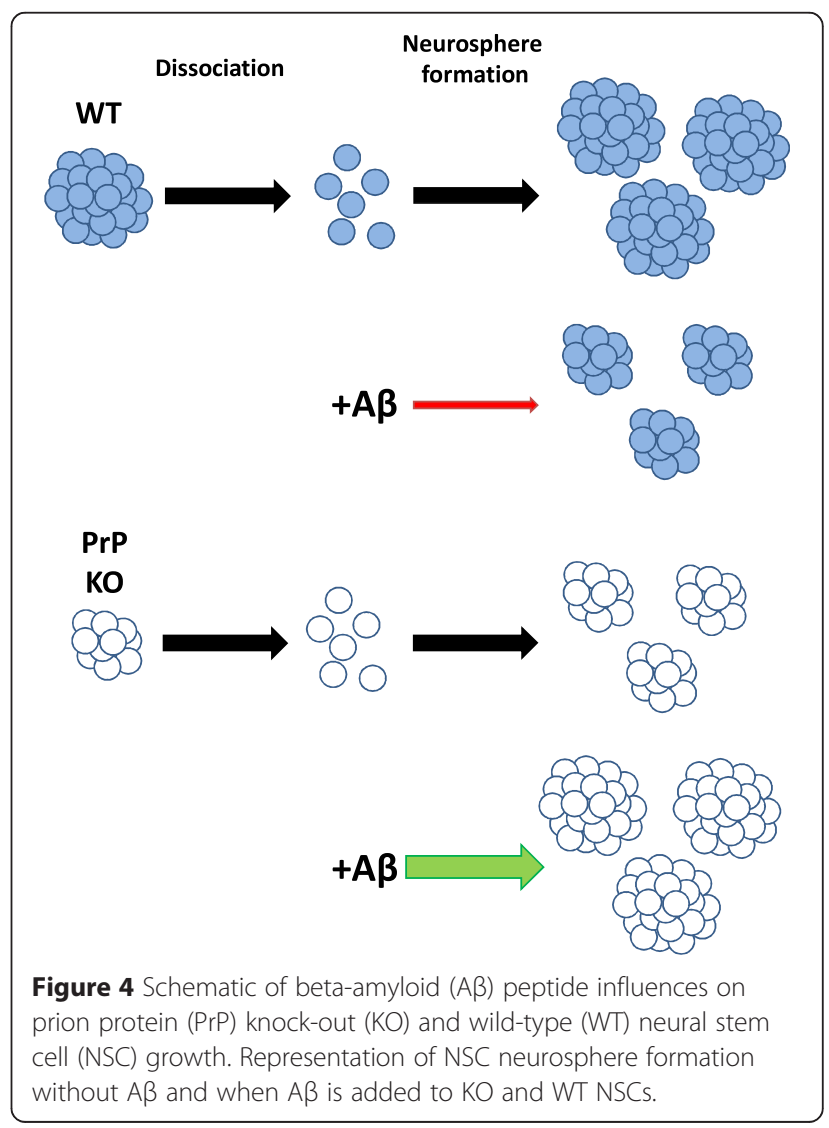


permit $A \beta$ stimulation of NSC proliferation, resulting in the increased neurogenic markers seen in AD brain tissue $[5,6]$.

\section{Conclusions}

This study has validated the hypothesis that the previously observed, $A \beta$-signalled changes in neurogenesis can be transduced through the $\mathrm{A} \beta$-oligomer receptor, PrP. In addition, we demonstrated that this signalling is more complex than PrP acting as a simple 'on' or 'off' switch for the pathway (summarised in Figure 4). Our data indicate that: i) congruous with studies using neuronal cells and mice $[16,29]$, differing $A \beta$ pathways are activated in the NSCs depending upon the presence and absence of PrP; ii) A $\beta$-PrP signalling inhibits NSC proliferation signals, although possibly monomeric forms of $A \beta$ act in contrast to the synaptotoxic soluble oligomers; and iii) variations in the basal expression levels of $\mathrm{PrP}$ might also account for some of the previous variability in, and disagreements over, NSC growth responses to $A \beta$. This dynamic and complex interplay of key factors regulating NSC growth provides significant new insight into the control of NSC self-renewal and further evidence of biologically significant interactions between $A \beta$ peptides and PrP.

\section{Additional files}

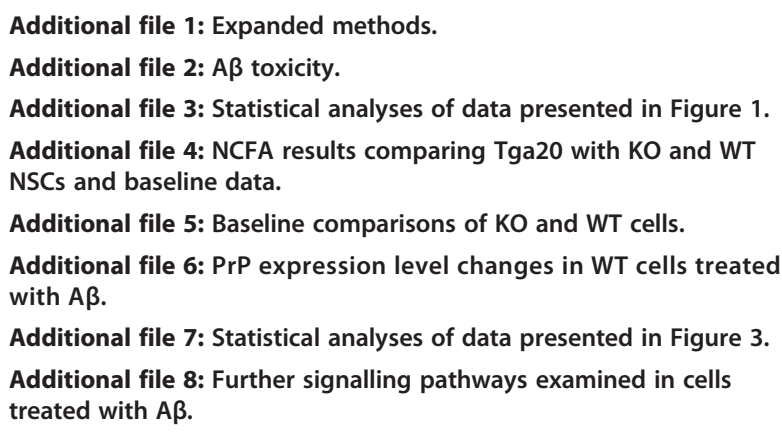

\section{Abbreviations}

$A \beta$ : beta-amyloid; $A \beta 3(p E)-42$ : pyroglutamated AB3-42; AD: Alzheimer's disease; ANOVA: analysis of variance; KO: knock-out; NSC: neural stem cell; PrP: prion protein; SGZ: subgranular zone; WT: wild type.

\section{Competing interests}

The authors declare that they have no competing interests.

\section{Authors' contributions}

$\mathrm{CLH}, \mathrm{CT}, \mathrm{QXL}, \mathrm{TMR}$ and BR performed experiments. CLH, SJC and $\mathrm{CT}$ analysed data. CLH, SJC, QXL, VL, SCD and VAL designed experiments. CLH designed the study and wrote the paper. All authors have read and approved the final version of the manuscript.

\section{Acknowledgements}

The authors would like to acknowledge Professor Colin Masters for his ongoing support and thank Dr Theo Mantamadiotis and Ms Gulay Filiz for their assistance with the cell cycle flow cytometry. This work was supported by an NHMRC program grant (\#628946) and the Victorian Government's
Operational Infrastructure Support program. SJC is supported by an NHMRC Practitioner Fellowship (\#APP100581), SCD by an ARC Future Fellowship (FT110100199) and TMR by an Alzheimer's Australia fellowship.

\section{Author details}

'Department of Pathology, The University of Melbourne, Melbourne Brain Centre, Melbourne, VIC 3010, Australia. ${ }^{2}$ Department of Medicine, Royal Melbourne Hospital, The University of Melbourne, Melbourne, VIC 3010, Australia. ${ }^{3}$ Florey Institute of Neuroscience and Mental Health, The University of Melbourne, Melbourne, VIC 3010, Australia. ${ }^{4}$ The Florey Department of Neuroscience and Mental Health, The University of Melbourne, Melbourne, VIC 3010, Australia.

Received: 23 October 2014 Revised: 27 January 2015

Accepted: 25 March 2015 Published online: 11 April 2015

\section{References}

1. Selkoe DJ. Soluble oligomers of the amyloid beta-protein impair synaptic plasticity and behavior. Behav Brain Res. 2008:192:106-13.

2. Portelius E, Bogdanovic N, Gustavsson MK, Volkmann I, Brinkmalm G, Zetterberg $\mathrm{H}$, et al. Mass spectrometric characterization of brain amyloid beta isoform signatures in familial and sporadic Alzheimer's disease. Acta Neuropathol. 2010;120:185-93.

3. Moore BD, Chakrabarty P, Levites Y, Kukar TL, Baine AM, Moroni T, et al. Overlapping profiles of Abeta peptides in the Alzheimer's disease and pathological aging brains. Alzheimers Res Ther. 2012:4:18.

4. Lazarov O, Marr RA. Neurogenesis and Alzheimer's disease: at the crossroads. Exp Neurol. 2010;223:267-81

5. Jin K, Peel AL, Mao XO, Xie L, Cottrell BA, Henshall DC, et al. Increased hippocampal neurogenesis in Alzheimer's disease. Proc Natl Acad Sci U S A. 2004:101:343-7.

6. Gomez-Nicola D, Suzzi S, Vargas-Caballero M, Fransen NL, Al-Malki H, Cebrian-Silla A, et al. Temporal dynamics of hippocampal neurogenesis in chronic neurodegeneration. Brain. 2014;137:2312-28.

7. Braak H, Braak E. Neuropathological staging of Alzheimer-related changes. Acta Neuropathol. 1991;82:239-59.

8. Kanemoto S, Griffin J, Markham-Coultes K, Aubert I, Tandon A, George-Hyslop PS, et al. Proliferation, differentiation and amyloid-beta production in neural progenitor cells isolated from TgCRND8 mice. Neuroscience. 2014:261:52-9.

9. Lee IS, Jung K, Kim IS, Park KI. Amyloid-beta oligomers regulate the properties of human neural stem cells through GSK-3beta signaling. Exp Mol Med. 2013;45:e60.

10. Zheng M, Liu J, Ruan Z, Tian S, Ma Y, Zhu J, et al. Intrahippocampal injection of Abeta1-42 inhibits neurogenesis and down-regulates IFN-gamma and NF-kappaB expression in hippocampus of adult mouse brain. Amyloid. 2013;20:13-20.

11. Peralta OA, Huckle WR, Eyestone WH. Expression and knockdown of cellular prion protein (PrPC) in differentiating mouse embryonic stem cells. Differentiation. 2011:81:68-77.

12. Steele AD, Emsley JG, Ozdinler PH, Lindquist S, Macklis JD. Prion protein (PrPc) positively regulates neural precursor proliferation during developmental and adult mammalian neurogenesis. Proc Natl Acad Sci U S A. 2006;103:3416-21.

13. Lee YJ, Baskakov IV. Treatment with normal prion protein delays differentiation and helps to maintain high proliferation activity in human embryonic stem cells. J Neurochem. 2010:114:362-73.

14. You H, Tsutsui S, Hameed S, Kannanayakal TJ, Chen L, Xia P, et al. Abeta neurotoxicity depends on interactions between copper ions, prion protein and N-methyl-D-aspartate receptors. Proc Natl Acad Sci U S A. 2012:109:1737-42.

15. Larson M, Sherman MA, Amar F, Nuvolone M, Schneider JA, Bennett DA, et al. The complex PrP(c)-Fyn couples human oligomeric Abeta with pathological tau changes in Alzheimer's disease. J Neurosci. 2012;32:16857-71a.

16. Um JW, Nygaard HB, Heiss JK, Kostylev MA, Stagi M, Vortmeyer A, et a. Alzheimer amyloid-beta oligomer bound to postsynaptic prion protein activates Fyn to impair neurons. Nat Neurosci. 2012;15:1227-35.

17. McColl G, Roberts BR, Gunn AP, Perez KA, Tew DJ, Masters $C L$, et al. The Caenorhabditis elegans A beta 1-42 model of Alzheimer disease predominantly expresses A beta 3-42. J Biol Chem. 2009;284:22697-702. 
18. Haigh CL, McGlade AR, Lewis V, Masters CL, Lawson VA, Collins SJ. Acute exposure to prion infection induces transient oxidative stress progressing to be cumulatively deleterious with chronic propagation in vitro. Free Radic Biol Med. 2011:51:594-608.

19. Sinclair L, Lewis V, Collins SJ, Haigh CL. Cytosolic caspases mediate mislocalised SOD2 depletion in an in vitro model of chronic prion infection. Dis Model Mech. 2013;6:952-63.

20. Haigh CL, Lewis VA, Vella LJ, Masters CL, Hill AF, Lawson VA, et al. PrPC-related signal transduction is influenced by copper, membrane integrity and the alpha cleavage site. Cell Res. 2009;19:1062-78.

21. Nussbaum JM, Schilling S, Cynis H, Silva A, Swanson E, Wangsanut T, et al. Prion-like behaviour and tau-dependent cytotoxicity of pyroglutamylated amyloid-beta. Nature. 2012;485:651-5.

22. Bouter $Y$, Dietrich $K$, Wittnam JL, Rezaei-Ghaleh N, Pillot T, Papot-Couturier S, et al. N-truncated amyloid beta (Abeta) 4-42 forms stable aggregates and induces acute and long-lasting behavioral deficits. Acta Neuropathol. 2013:126:189-205.

23. Heo C, Chang KA, Choi HS, Kim HS, Kim S, Liew H, et al. Effects of the monomeric, oligomeric, and fibrillar Abeta42 peptides on the proliferation and differentiation of adult neural stem cells from subventricular zone. J Neurochem. 2007;102:493-500.

24. Haughey NJ, Liu D, Nath A, Borchard AC, Mattson MP. Disruption of neurogenesis in the subventricular zone of adult mice, and in human cortical neuronal precursor cells in culture, by amyloid beta-peptide: implications for the pathogenesis of Alzheimer's disease. Neuromolecular Med. 2002;1:125-35.

25. Whitehouse IJ, Jackson C, Turner AJ, Hooper NM. Prion protein is reduced in aging and in sporadic but not in familial Alzheimer's disease. J Alzheimers Dis. 2010;22:1023-31.

26. Whitehouse IJ, Miners JS, Glennon EB, Kehoe PG, Love S, Kellett KA, et al. Prion protein is decreased in Alzheimer's brain and inversely correlates with BACE1 activity, amyloid-beta levels and Braak stage. PLoS One. 2013;8:e59554

27. Liou YC, Sun A, Ryo A, Zhou XZ, Yu ZX, Huang HK, et al. Role of the prolyl isomerase Pin 1 in protecting against age-dependent neurodegeneration. Nature. 2003;424:556-61.

28. Rushworth JV, Griffiths HH, Watt NT, Hooper NM. Prion protein-mediated toxicity of amyloid-beta oligomers requires lipid rafts and the transmembrane LRP1. J Biol Chem. 2013;288:8935-51.

29. Gimbel DA, Nygaard HB, Coffey EE, Gunther EC, Lauren J, Gimbel ZA, et al. Memory impairment in transgenic Alzheimer mice requires cellular prion protein. J Neurosci. 2010;30:6367-74.

\section{Submit your next manuscript to BioMed Central and take full advantage of:}

- Convenient online submission

- Thorough peer review

- No space constraints or color figure charges

- Immediate publication on acceptance

- Inclusion in PubMed, CAS, Scopus and Google Scholar

- Research which is freely available for redistribution 